\title{
The Jay's wing by Ivan Franko: imaginary drama dialogue
}

\section{"El ala de Jay" de Ivan Franko: dramaturgia del diálogo imaginario}

\section{Tetiana Virchenko}

Dr. in Philology, Professor of Department of Ukrainian Literature and Comparativistics. Borys Grinchenko Kyiv University.

ORCID: https://orcid.org/0000-0001-7953-2285

\section{Roman Kozlov}

Dr. in Philology, Professor of Department of Ukrainian Literature and Comparativistics. Borys

Grinchenko Kyiv University.

ORCID: https://orcid.org/0000-0001-5912-9106

Received 02-12-20 Revised 04-25-20

\section{*Correspondence}

Email: ivannovadremova29@gmail.com
Accepted 01-13-21 On line 10-21-21

\section{Cite as:}

Virchenko, T., Kozlov, R. (2021). The Jay's wing by Ivan Franko: imaginary drama dialogue. Propósitos y Representaciones, 9 (SPE1), e910. Doi: http://dx.doi.org/10.20511/pyr2021.v9nSPE1.910 


\section{Summary}

In accordance with European tendencies, modernization penetrated the Ukrainian culture as an "artistic philosophy" (by S. Pavlychko). Ivan Franko, as an artist and thinker, underwent several evolutionary changes during his life. The modernist artistic heritage of I. Franko existed in the context of the works of Lesia Ukrainka, O. Kobylyanska, V. Stefanyk, M. Kotsyubynsky and M. Cheremshyna. But in the literary debate, Franko remained a staunch opponent of those who urged Ukrainian writers to abandon realism. I. Franko's short story The Jay's wing. From the notes of a hermit is an experiment of literary form. We aim to analyze various aspects of this literary phenomenon, which will clarify the Ivan Franko's role in the process of Ukrainian literature modernization. This short story does not provide a lot of material for the classical narratological method. Therefore, it makes sense to combine it with psychological interpretation and semiotic observations. One of the directions of expanding the possibilities of semiotic interpretation through narrative observations is the involvement of the conceptual sphere of cinematic poetics.

Key Words: interpretation, story, drama, dialogue, The Jay’s Wing by Ivan Franko.

\section{Resumen}

De acuerdo con las tendencias europeas, la modernización penetró en la cultura ucraniana como una "filosofía artística" (según S. Pavlychko). Ivan Franko, como artista y pensador, experimentó varios cambios evolutivos durante su vida. La herencia artística modernista de I. Franko existió en el contexto de las obras de Lesia Ukrainka, O. Kobylyanska, V. Stefanyk, M. Kotsyubynsky y M. Cheremshyna. Pero en el debate literario, Franco siguió siendo un acérrimo oponente de quienes pedían a los escritores ucranianos que abandonaran el realismo. I. El cuento de Franko "El ala de Jay. De las notas de un ermitaño "es un experimento con una forma literaria. Nuestro objetivo es analizar varios aspectos de este fenómeno literario, lo que aclarará el papel de Ivan Franko en el proceso de modernización de la literatura ucraniana. Este cuento no proporciona mucho material para el método narratológico clásico. Por tanto, tiene sentido combinarlo con la interpretación psicológica y las observaciones semióticas. Una de las direcciones para expandir las posibilidades de la interpretación semiótica a través de las observaciones narrativas es la participación de la esfera conceptual de la poética cinematográfica.

roceso de modernización de la literatura ucraniana.

Palabras clave: interpretación, cuentos, drama, diálogo, "Jay's Wing" de Ivan Franko.

\section{Introduction}

The beginning of the XX century is the period of the early modernism in Ukraine. In accordance with European tendencies, modernization penetrated the Ukrainian culture as an "artistic philosophy" (according to S. Pavlychko). The literature of modernism was formed as a clash between the philosophy of A. Schopenhauer, F. W. Nietzsche, H.-L. Bergson, which caused the anti-positivist break, and bourgeois values:

The doctrine of progress, the confidence in the beneficial possibilities of science and technology, the concern with time (a measurable time, a time that can be bought and sold and therefore has, like any other commodity, a calculable equivalent in money), the cult of reason, and the ideal of freedom defined within the framework of an abstract humanism, but also the orientation toward pragmatism and the cult of action and success $-<\ldots>$ key values in the triumphant civilization established by the middle class. (Calinescu, 1987: 41-42)

The achievements of psychology, such as The Interpretation of Dreams by S. Freud, contributed to the attention of writers to the inner world of the characters, to escape from the world, self-contemplation, conflicts of the rational and the subconscious. Since Galicia was part of Austro-Hungarian Empire at the time, its Ukrainian culture actively absorbed the latest ideas 
of German philosophy and science, particularly, the ideas of F. W. Nietzsche, i.e., the ability of a human to rebel, along with the desire for freedom, liberty and more.

Ivan Franko, as an artist and thinker, underwent several evolutionary changes during his life. Not all of them, though, relate to the external factors, such as the events in the public and his private life. Some changes occurred due to the synthesis of spiritual, ideological, psychological and social factors. This is especially true for the period of 1895-1908, called by Ye. Nakhlik the "Third Franko". He connects this period with the death of M. Drahomanov, overcoming his influence, withdrawal from the active political life, and the writer's attention to various stylistic trends of the early Ukrainian modernism (Nakhlik, 2017). For this path was difficult, scientists define this period differently in various domains of creativity: 1901-1906 for poetry (Korniichuk 2004: 18-19; Tykholoz, 2009: 94-95), 1898-1904 for drama (Kozlov 2012: 145), 1900-1913 for prose (Lehkyi 2019: 24). This period of modernist poetics is characterized by elements of symbolism, interest in intuition, emotions and instincts, changes in writing techniques, the tendency to dialogization of prose, as well as the flow of consciousness. In this article we will consider Ivan Franko's short story The Jay's wing. From the notes of a hermit as a sample of the experiment of a realist writer who tried on the role of a modernist. We assume that the essence of the experiment was to build a multilevel prose text with hidden dialogization. We aim to analyze various aspects of this literary phenomenon, which will clarify the Ivan Franko's role in the process of Ukrainian literature modernization.

\section{Theoretical framework}

The year 1898 was significant in the history of Ukrainian literature — one hundred years passed since the publication of Ivan Kotliarevsky's Eneyida, the Literaturno-naukovyi vistnyk launched, and the crisis of populism became evident. Prominent contemporaries of Franko, who defended populist tendencies in Ukrainian literature, were Ivan Nechuy-Levytsky (Muravetska, 2018) and Borys Grinchenko (Kozlov 2018). At the same time, in colonized Ukraine, populism was seen as a way of artistic thinking, a culturological approach and a political ideology. Therefore, the confrontation between populists and modernists in Ukraine was of a different nature than in Europe, where "The modernist aesthetic conserves notions of tradition, perspective and analysis even as it acknowledges the impossibility of objective understanding. Integral to the development of modernism, though, was an avant-garde ethos that pursued fleeting moments of subjective experience without seeking to conserve" (March-Russell, 2009: 210).

But in Ukrainian literature, the revolt against realism is not merely an aesthetic position but also, fundamentally, a political one. Neither Joyce nor Proust need to defend the legitimacy of the creative intelligentsia or its role in determining the cultural agenda. In Ukraine the situation is different. The aesthetics of realism are tied to the politics of populism. The poetic debate between Voronyj and Franko and the essays of Jefremov clearly show the political nature of the prevailing cultural criteria that the Modernists attack. Thus, the modernist writer in Ukraine rebels not only against literary realism but against political populism as well. (Tarnawsky, 1991: 265)

However, at the end of the nineteenth century, modernism, as a worldview that opposed populism, had neither its own theorist nor its own publication. Only Lesya Ukrainka in the report Little Russian Writers in Bukovina (1896) used the term "moderne" to denote the artistic tendency. A few years later, S. Yefremov considered M. Vorony's call to start the Ukrainian Almanac as a manifesto of modernism. Accordingly, the modernist artistic heritage of I. Franko existed in the context of the works of Lesia Ukrainka, O. Kobylyanska, V. Stefanyk, M. Kotsyubynsky and M. Cheremshyna. But in the literary debate, Franko remained a staunch opponent of those who urged Ukrainian writers to abandon realism.

We consider this bifurcation of the author's consciousness to be organic for an experienced writer, who, following the fashion, was conducting experiments with form. G. (Grabowicz, 1991) believes that it is unacceptable for a scientist to succumb to ideology- 
generated seeming contradictions. Otherwise, some absurd statements arise: "If one is a 'populist' or 'positivist', one cannot be a "modernist"; if Franko writes his diatribes (some of them even good-natured) against Voronyj and his ilk, he cannot then also write 'Ziv'jale lystja', or 'Poxoron', or, for that matter, that oddly realist and moralist-cum-fantastic 'Jak Jura Sykmanjuk briv Ceremos' in 1991. It is fin de siècle that is the time of restructuring the genre of the classic short story:

After 1920, there emerged a new type of short story that renounced all the characteristic traits we have described. Classic short stories continued to be written - and continued to sell but beside them the twentieth century saw the rise of something quite different, which corresponds to what Clare Hanson calls "short fiction", and which she has showed to be linked with the advent of Modernism. Structure was no longer based on antithesis or even paroxysms, and the distant look at the subject completely disappeared, together with the author's and reader's superior attitudes; monologism was no longer a standard feature. (Goyet 2014: 187-188)

However, the rejection of the monologue narrative, in addition to the continuous dialogic nature of prose, was embodied in another form. The actualization of the genre of a letter-novelette is one of the signs of modernization of literature. Like the dramatized short story, it gained popularity in the 1920s, such as Letter from an Unknown Woman by S. Zweig in 1922. Some of the earlier authors include E. T. A. Hoffmann and A. Kuprin.

I. Franko's short story The Jay's wing. From the notes of a hermit completes the collection In the bosom of nature and other stories in 1905 and is the best in it. The collection includes his works of 1880-1905, in which the signs of romantic, nature-romantic, realistic, unrealistic, impressionistic and symbolist styles are clearly visible. Dramatization and dialogization of prose became also noticeable, particularly in the stories of that time Blackthorn in the leg in 1902, How Yura Shykmanyuk waded Cheremosh in 1903 along with Odi profanum vulgus in 1899 and Dryad in 1905 which were part of this collection as well.

The bibliographic records of the literature about Ivan Franko indicate that scientists have not taken proper notice of the literary read The Jay's wing (1905, cited by translation, 1935). The situation did not change substantially in the 1990s. The amount of researches remained insignificant. Only stylish (romanticism) and stylistic aspects drew the attention of the scientists. However, in the 2000s certain advance was brought into view. And that is when specialists in literature started to pay attention to the internal structure of the prosaic work (Lutsak, 2000), the poetics elements (Huniak, 2003., Boiarska, 2011), and the principles of creation of the images (Durkalevych, 2007) as well as the psychoanalytic interpretation. Scientists made an attempt to view this short story in the context of the European artistic-cultural searches (Boiarska, 2011). It seems apparent that this artistically valuable writing deserves significantly more of scholars' attention.

As an initial point in their researches, almost each of the scientists agreed upon viewing this literary work as a combination of the diary records and the letter all in one. According to $\mathrm{O}$. Vekua, such a synthesis gives a possibility to "create a certain $\langle\ldots>$ dramatic dialogue $<\ldots>$ and to put it on stage" (2002: 53). Among all the scientific interpretations of The Jay's Wing, the study of I. Denysiuk (2001) stands out notedly by the depth of the analysis and the genuine admiration for the heritage of I. Franko. The specialist of literature emphasizes that the dramatic dialogue executes a number of functions, such as creating a dramatic effect, highlighting psychological moments along with providing staginess, conflict tension and the contrast of this literary work. However, the main focus of the scientist's study was on the genre features investigation of the short story.

According to the laws of dialogue, there are two acting figures in the literary read. Massino is an unsociable person, the day before his fortieth birthday. His past, full of dreams and love ("And I believed, dreamed and loved... My soul basked in a rosy vapor, building golden 
castles in the air and lending hues of beauty and life to that which was merely a conventional lie...") collapsed unexpectedly. After that he needed three years of daily practice to gain emotional equilibrium ("I shall look at everything sensibly, practically, thoughtfully, and first of all - calmly, peacefully, as becomes a man of forty") and aspiration to follow the new value orientation which is living without fetters that may come in form of any public relations.

I. Franko is known as an ideological inspirer of the feminist movement in Ukraine. He studied folklore from the standpoint of feminist criticism, translated the works The Subjection of Women by John Stuart Mill, and Women's movement in France and Germany by Käthe Schirmacher, helped organize the first women's almanac. However, his departure from politics and ideological reorganization resulted in literary disagreement with Nataliya Kobrynska, which in 1898 escalated into an epistolary discussion. In this discussion, he advocated the preservation of national immanence in modernist aesthetics. Most of his worldviews are manifested in the story telling about a woman's life in the world of men.

Marya (Manya, Maniussia) finishes her letters with Your Little Jay. Instead of the age or appearance, the writer uses the description of her behavior for revealing the character of the woman: "She whose mysterious and impudent disappearance brought her father to his grave, and threw me from the dashing stream of social life into this quiet, isolated landing".

For the development of the action, Ivan Franko elects the letter that gratifies ("I love such mysteries, for my life is void of them") and intrigues the addressee at the same time ("What can be the contents of this envelope"). The Massino's presentiment is the writer's hint at the unexpected changes addressed to the serious reader: "Maybe this letter... become the box of Pandora, out of which snakes will creep and poison my life, ruin my fortress, and spall today's holiday". Shaking hands, leap of the heart and cold body sensations are explicit physiological and psychical evidence of the fact that the letter will eventually end up to be fatal, and its author is a significant person in the man's life.

Thus, the writer does not raise simple questions with obvious answers for readers to respond. Therefore, the explanation of the features of the content and the form of the letter, able to change the world view of the man and ruin his so long-cherished aspiration to be independent, is to become a research task. To do this, consider the two plans of the narrative in the text as an imaginary dialogue. The leading role obviously belongs to a woman. The men's role is dependent, it is a course of reactions to manipulative statements from a letter read by Massino. But the main role still belongs to the author, according to whose plan this dialogue unfolds. The unusual form of the short story (which can be called a "commented letter") indicates that the conceptual idea lies somewhere between the realism and the modernist poetics.

\section{Methodology}

This short story does not provide a lot of material for the common narratological method. Therefore, it makes sense to combine it with psychological interpretation and semiotic observations. As J. Pier notes:

Framing the two basic dimensions of narrative in terms of the translatability between semiotic systems rather than in analogy with signified and signifier constitutes an epistemological reorientation of considerable significance for narratology. When narrative is viewed in terms of semiotic functions, for example, it calls for a reexamination of a narrative grammar based on 'a profound unity between language and narrative,' as advocated by Todorov, while the inferential nature of the sign represents a powerful alternative in narrative studies to the idea that textual manifestation "stands for" narrative content - an alternative explored in detail in The Role of the Reader. (2003: 86-87) 
One of the directions of expanding the possibilities of semiotic interpretation through narrative observations is the involvement of the conceptual sphere of cinematic poetics. "Comparative narratology is less a matter of pointing up resemblances or differences between two semiotic systems than of deploying the cinema-literature shuttle in order to forge more precise and productive concepts" (Jost 2004: 71). But "the semiotic materials of film and novel are not the same, and one cannot mechanically transfer concepts forged in one domain to another domain. But it is also useless to try to solve these problems through imprecise metaphors" (Jost 2004: 79). Thus, we should limit ourselves to using the term frame to define a short episode, during which the plot time is not interrupted. Particular attention should be paid to the temporal structure of the novel, as the author emphasizes it from the very beginning. It is the manipulation of time (the time to read the letter and the time to experience the emotions that the author and Marya assign to Massino) that leads the story to such a spectacular finale.

\section{Results and discussion}

Ivan Franko does not avoid the description of action development. Massino has planned the time from seven to twelve - listening to the overture of Rossini, viewing the flowers at the florist's, having a drink and taking a bite, reading a new article about Jesus Christ, looking through the fresh periodicals and even listening to a specially selected ("set of new records for the phonograph"). There are three artistic details implying that these plans will not be put in reality: two glasses on the festive table put by the servant Ivan, a doorbell ring in the antechamber ("Clinkclank", in the future this sound will indicate each change) and the visual image of the human skull as an evidence of the unhealed wound: "Whenever a young girl, especially a brunette, smiles to me, I imagine that the flesh on her face becomes transparent, and a frightful skull grins at me". To understand the artistic mechanism of foreseeing, implemented by the author, it seems necessary to interpret the letter's structure and language, as all this complex of manipulative techniques will be affecting the world outlook of this unsociable person and inevitably destroying it.

The first thing the woman makes an appeal to is his memory: "Do you remember me?" The experiencing has been enhanced by the fourfold reiteration of the question. The woman, he once loved, urges him to recall the laughter, the mood tonality, her clothes and the places they used to meet at ("Do you remember the Meadow, where we first met?").

Marya is well aware of the fact that the recharge of emotions is facilitated by the comparison to the nature images ("Do you remember my laughter? You loved to listen to it. You would come to me from after, drawn by the sound of it. Can you hear it now, over the ocean, steppes, and mountains? Does it tremble in your ear together with the wind? Does it mingle with the rays of the setting sun?"). To spark the emotions she also uses the recollections about the least actions and remarks of the man ("I gave you my hand. You kissed it, and I felt how your lips trembled under your dark mustache. I asked you to take me home... You wondered that there were grouse in this forest, for you had spent your entire youth here and had never heard or seen one").

"A skilled stage-director" Jay knew that it would have an influence: "Oh, I know that you remember me! You must remember! You could not forget me!"

She already checked her stage-directing abilities to build relationships three years ago, when she "called everything to may aid: the sun and forest, the purple sunrise, the enchantment of midday, and the melancholy of night".

Ivan Franko gradually prepares a reader to Jay's victory, especially since she has always been a victress in these relationships because she has exactly followed the drawn-up plan: "I decided to drag you off your pedestal with irony, laughter, and jest .It did not work, for your soul 
was shielded by patience. Then I employed other methods: heartiness and generosity: and finally the strongest, the last - my love. This you could not withstand — and I conquered!"

The woman's narration does not contain only affirmative sentences. Using interrogatives, she engages the interlocutor in the imaginary dialogue, which, as it seems obvious now, is very well-directed. Thus, the question "Ha, ha, ha! My artist, are you thankful to me for my part?" brings about a non-acceptance and aggression: "Enough!"

Massino acknowledges that the appeal to the memory by the frequent reiteration of the same question is slowly and painfully destroying the hidden recollections about the relationships that once were being built based on sincerity: "I gave you all, all that was beautiful and pure in my soul, while you played with my feelings".

Jay has attained the first desirable effect; therefore, she is making a plea: "Do not be angry with me, my Massino!"

The next step is awakening of the remembrance of the physical sensations. For this purpose, Jay resorts to proceeding with questions, appealing to the man's memory: "Oh, how you scolded me then, when among three series of kisses I christened you thrice".

Jay dedicates the large fragment of the letter to prove her innocence in their separation putting forth numerous arguments.

Among them are the femality ("Can a woman act differently? What to men, who are harder and less keen, seems mere coquetry, display, that forms the most intimate manifestations of woman's nature. It is to them as simple and inevitable as breathing with their lungs and walking with their legs"), the masculine ability to influence a woman ("you came into my life like the hot sun which forces the flowers to open into full bloom and pour forth their precious fragrance"), and the appeal to admit that the time spent with her was the best thing in his life ("Was not the summer in the woods the most beautiful time in your life?").

And the last, most influential argument was not merely the shifting of responsibility ("I did not leave you, - you did not know how to hold me"), but the accusing him of selfishness and disbelief in her sincerity: "You accepted my caresses, all the tokens of my young, awakened feeling with the passivity of a sybarite, — tenderly appreciatively, but remaining within the limits of your egoism".

The woman realizes that it is necessary to tell about her own sufferings: "I suffered much more, a thousand times more than you, and for my sufferings", with the blurred letters on the piece of paper enhancing the impression. It instantly evokes a doubt in the man's mind; though, this doubt is easily fading out yet.

For the sake of keeping the man's attention, she explains the presence of the jay's wing in the envelope. The "stage-director" needs to articulate clearly who bears responsibility for the ruined relationships; therefore, she decides to choose the jay, which so magically influenced Massino, to play this part. At the same time, Marya begins to prepare the man for her possible visit: "If there is still a spark of love for me in your heart, a drop of desire to see me, - it shall draw the other wing, the second half of my soul to you".

This episode creates the mood contrast in the dialogue: "To be truthful, Mis Manya, I am not a bit touched". This mood was indisputably guessed and envisaged by the sender: "I know, Massino, that you hate sentimentality. You must be tired of my writing and ask yourself". The woman also needed it to highlight her ability to penetrate to the most secret depths of his soul: "That woman is the Devil himself! It seems that when she wrote, her soul conversed with me, and 
while she wrote down her phrases, her eyes of a lizard followed every move of my soul. She leads a silent dialogue with me, answering every question that is born in my brain".

O. Chyrkov in his theoretical studies $(2006,2013)$ proves that a play-writer able to think cinematographically reaches a stage potential quicker.

Ivan Franko has divided his literary work into sections, similarly to the publishing approach, for organizing a storyboard in the The Jay's wing. In addition, the remarks of Massino often end with a phrase "Let us read further", which is also kind of a frame separation, identifying new information and emphasizing the man's willingness to perceive it.

The remarks of Jay contain the large fragment of confession concerning her past life, also divided into frames. The first of them begins with the promised surprise: "Do you know that I am coming back to you? I shall soon bury my husband and be free". Further it is reinforced by its inevitability once more: "It is immaterial to me whether you will welcome me or east me away. It does not matter! I only want to see you again and clasp your hand. After that - who cares".

Along with that, Manya lets him know about the reality of her own life.

Each sentence is an informative statement: seven times married, expecting the death of her husband lying legless.

The next frame is separated by the moan of her dying husband. This phonic message reminds the recipients of the power of sound and color in creation of visual images. In this regard we can remember the women's voices, salons' lights and the faint piano sounds from the past life of Massino.

In this frame the woman emphasizes that she is writing her confession at night, and her room is filled with autumn aromas. But along with the night serenity, her longing for protection grows: "I am sitting right near the bed and writing, conversing with you, my Massino. I am leaning against you like a poor, unfortunate orphan, wandering in a strange world. This contact with you leaves a softness in my soul. I feel the presence of a higher, nobler spirit".

Obviously, by this Jay accentuates the place of Massino in her own life, even distantly. And it is not enough for her, that is why she is asking for permission to confess, despite the fact she has already began doing it long ago: "I do not ask you to forgive my sins, I ask nothing just listen to my confession. After that do as you please".

Having received an imaginary consent ("Let us listen to the confession of our jay from Port Arthur"), the woman started out with her memories about their last meeting. She again resorted to the well-tried expedient - reminded him that she remembered the man's tastes which were his liking for berries, and his ambition to participate in public affairs.

The confession implies the revelation of her own guilt. Jay probably sees it in her own frivolousness: "I laughed very much that evening".

What notedly strikes the researcher's eye is that Jay does not pay attention to the coherence of the narration. She relies more on emotional influence than on correlation of facts. If it hadn't been so, she wouldn't have missed out that accusing him of disbelief in her feelings that urged her to escape, obviously contradicts this remembrance: "Your eyes rested upon me with such assuredness and love".

Ivan Franko again returns the reader's attention to the artistic hints. 
That late evening the hoot of an owl caused an inner agitation in Massino. It seemed to him that the wicked demon "laughs and mocks human faith, human hopes", but his childish naivety assured him that the feelings of lovers were protected by sincerity and frankness. Nevertheless, this faith contributes to the creation of the character of "poor, stupid Massino!"

Massino is making an ironical judgment on Jay: "And you, wise, strong clever Marya, have you attained great happiness? Why, then, does this letter bear traces of your tears?" The man not only acknowledges that he remembers all the details of their last meeting ("The moment before our parting is very vivid in my memory too"), but also complements the written by his own recollections. This resonates with Jay, who also felt that the changes she had chosen in her life would not bring happiness into her future.

Indisputably, Jay is important for Massino, as the author stresses that the man remembers all the details of her dress: "You wore a dress of red muslin with white dots. On your bosom was pinned an opal brooch, a metal comb held your hair". The picture of this dress is a meaningful detail of the dialogue. Jay keeps it as "the dearest memory" and decides that this dress is what she is going to wear when appearing in front of Massino again. Therefore, in the last frame, when the woman is sitting "in her thin red dress with white dots" in the antechamber, neither the reader nor Massino has doubts who she is.

The continuation of Marya's confession can induce only moral condemnation caused by her distinctly indifferent attitude toward her father ("There was not a drop of sorrow in my soul") as well as her insincerity towards Massino. The woman accused Massino of egoism as one of the reasons she escaped from him. Indeed, in the last dialogue between "sweethearts" Massino claimed: "Happiness is a fact which needs no proofs... I am happy".

Observably, in such understanding of happiness there is no place for Jay, for the aspiration to make her happy. But egoism is what determines Jay's behavior as well. After finding out about her father's death, the woman does not feel any sorrow, regret or guilt. Her inflated self-worth caused the grievances against her father who had been considering her a criminal till his dying day: "Me, who was so proud, pure, honest and innocent then".

Realizing her status of a married woman, Marya experiences a surge of emotions. It is easily perceptible that both the marital status and physical harmony with a man are the most essential values for her: "This confirmed title gave me great joy, and I kissed Henris madly". Even having discovered a criminal nature of her husband, she experiences both fear and satisfaction given by his "strength, intelligence, and energy".

It is possible to assert that power is the ultimate masculine trait able to arouse love in Jay. After Henris had disappeared, Sigmunt became Maniussia's lover: "When Sigmunt was to me the chief of the gang, surrounded by mystery and fatalism his personality interested me, and I used to think that I could love him". Notedly, Jay tries to make Massino jealous by her frank recitals about her infatuation for the masculine character traits and the peculiarity in the relationships with them.

For example, with the next husband - Volodimir Semenovitch — she has quickly gone through their honeymoon and does not even condemn his drunkenness ("He was very pleasant and mirthful when drunk"), though this is exactly what has made her a martyr in these relationships.

To express her feelings, Marya uses a sense-pause: "One vice attracted another and he became a passionate gambler. I found out about his card passion when he lost all he had,... including me". To pump emotions up, she allocates a considerable fragment of the confession to the detailed description of those night events. Ivan Franko accentuates the horror of the situation 
by the sound images: "I remembered that dreadful night. The storm raged, while I sat alone, waiting for Volodia”.

It is perfectly expected, that the man who stakes a human being in a card play has an ugly look, too: "Volodia came in and with him was a giant dressed in a fur coat, with a red beard, a stout red face and a flat nose". It is noticeable that certain frames of the confession end with an allusion to her suicide attempts. Probably, this is dictated by her intention to win his compassion, especially considering the fact that the woman "was under devilish influence" of Sigmunt, her husband's partner.

The further narration about her recollections has a frame structure, too: the woman uses a time contrast, narrating in rotation about the past and the present, when she had to look after her sick husband. The recital about her moving to "the snowy plains of northern Siberia..." occasionally interweaves with the explosions of the Japanese bombs blowing up the houses.

Marya is not satisfied with the sympathy evoked by her story about Nikanor Ferapontovitch, the next husband of her, whose property she became ("But his lack of culture and crude nature made him loathsome to me"). Therefore, the woman declares her desire to close the confession summarizing her own live experience as follows: "But, — what are my sufferings, my bloody tears to you? No, - hurry, hurry..."

Therefore, the next frames shoot past rather quickly — the attack of the tramps, the fight, the death of Nikanor Ferapontovitch, the meeting with her former husband, Sigmunt, the conference on the forest glade, her self-awareness as a booty of Sashko, who was hung up already two weeks later, her passing into captain's ownership and Sigmunt's disappearance.

The dynamic and intensity of the events happening within these terrible two weeks are achieved by the usage of the short simple sentences. Due to them, the semantic field of the utilized verbs makes an impression of the permanent atmosphere of fight, competition and outrage dominance: attacked, sparkled, defended, threw, broke, tore out, weakened, tormented, mocked, hunted, caught, rose, reached, abandoned, hung up, took, did not see.

The life with the correctional officer was the worst. Having the legal wife, "evil as a viper", he used to drink a lot and beat them both. That is when the desire to drown herself came back to Jay, but an unexpected circumstance changed the situation: "I happened to come across a train of soldiers bound for China. I went with them". The last phrase of this frame - "It did not matter to me with whom and where to..." - witnesses that Marya stresses the prevailing feeling of meaninglessness of her own life. The three point put at the end of the quotation dropped a hint at the change. It became the time shift which meant the return to the present events.

The confession letter ends with the word about the death of Mykola Fedorovych and the goodbye words implying the hope to meet in the Kingdom Come: "We shall meet yet! If not here, then - I lost this faith, I could no longer live". However, these words are the next cunning, because Jay has already declared her intention to come back to Massino no matter what. The final words of the letter "Till we meet again!" once again confirm this idea.

Massino does not accept this confession as true, explaining it to himself as a romanticism of a woman's nature. This short frame indicates that the man is usually guided by his mind. However, the letter has been composed in a specific way to influence his emotions. And eventually, this has been attained: "It is a quarter to twelve. My God! And I am still sitting over this letter, which is now wet with my tears!"

The five hours (from seven to twelve) set off by Ivan Franko, Massino has not lived according to the plan at all, to be exact, not according to his plan. The mood of Massino has changed fundamentally. He has forgiven his loved Jay, because those living feelings, that he used to bottle up diligently, must stay alive. The man is ready for the meeting with Jay to confide in 
the new life: "My little dove! Where are you? Let your spirit come from over the far seas in this last hour of the Old Year and touch me with its wing! Let a breath of real, endless, suffering life come to my frail, useless existence! Perhaps I will wake up, break my bonds and start a new life!"

The ringing of the doorbell and the steps in the salon are what Massino sincerely longs for. The content of the confession letter has been continuously preparing Massino and the readers for the realization that the meeting will eventually become reality. Therefore, the question of Massino addressed to Ivan, his servant — "A lady? Young or old?" — is fully complied with the tradition of dialoguing. In the cold antechamber, Jay took off her fur coat, anticipating correctly the host's questions about the visitor's identity. It was a concluding chord of the carefully elaborated, planned action. And presented by the author demand "Show her in!" was necessary for its harmonious sounding.

The concordant artistic integrity of the work has been attained by means of Massino and Marya's remembrances, jointly complemented. They create the expressive picture of their mutual past and fully expose the characters of the participants of the dialogue. Such a feature of an artistic structure is especially important for dramaturgy. Worth mentioning is also the use of the leading visual-material image of the dress that penetrates the memories of both characters and connects them to the reality.

Nevertheless, the author contrasts the images of Massino and Marya on the basis of coloristics and the tempo-rhythm of their lives. Contrary to the expectations of a recipient to see the woman, especially the martyress, in light tones, Marya is associated with dark colors, at least because of her appeal to the men full of dark force during all her live adventures. The lonely quiet life of Massino distinctly contrasts with the reckless speed of Jay's.

And the meaningfulness of Massino's life (taking into account at least the planning of the New Year night) is incomparable with the inanity of the life of his sweet one. However, this seeming fatuity is exactly what compels Massino to spend all five hours, previously allocated for the worthy leisure, on reading the letter (with breaks for the struggle of logic with emotions and tears).

\section{Conclusions}

Each of the participants of the dialogue acts (writes/reads) consciously. The deliberate influence of Marya on the psyche of Massino (the references to the time spent together, the recital of the unhappy life) has yielded the result - his aggression changed to sympathy and forgiveness. Massino's unwillingness to interrupt reading is the most expressive evidence of Jay applying consciously well-thought-out narrative tactic. Definitely, it is facilitated by the volume of the letter; however, the crucial point is the dynamics of the plot. Not only seems the logic of the narrative well-thought-out, but also the sequence of the sentences.

Each semantic unit (frame) in the letter of Jay is full of visual potential. The sentences of the letter have such content that the man does not have an intention to "shorten" them. And consequently, the reader of this novella cannot have such an intention as well, which indicates the artistic mastery of the writer. The two levels of the work, the letter and the diary, hold the reader's attention so firmly that the narrowing down to any of the levels does not take place. The Jay's letter as a remembrance of her past life is perceived by Massino as a present whirlpool of events, pulling him in. He does not expect the changes caused by such reading in his own consciousness.

Though it is notably, that by granting his hero only the inner feeling, the author prepares the reader for the anticipated finale. Lastly, it is worth noticing that, while reading the letter, Massino kind of "falls back into the past". And this is how Ivan Franko eliminates the time borders and, consequently, renders composition integrity to the work. 
Was Franko finally able to create a modernist work? Yes and no. The Jay's wing is a successful experiment with narrative structures, with dramatization of the text, with the hidden intentions of the author of the letter and with the obedient reactions of its addressee (cf. Letter from an Unknown Woman by S. Zweig). It is a paradoxical interaction of the lovers at a distance by means of solely the written letters and the memory. It is a stretched in time plot, condensed and emotionally conveyed on the pages of the letter.

At the same time, the content of the short story is quite realistic. The topics touched by the author are relevant for his time: the place of women in the world of men, emancipation, the right to feelings, the right to loneliness. Geographical and historical realities are clearly defined and thought through.

The duality of this short story expressively illustrates the transitional stage of the great process of modernization in Ukrainian literature. And it is in such "hot spots" that we should look for the energy which became a driving force behind this modernization for the upcoming half century.

\section{Bibliographic references.}

Boiarska, L. (2011). "Soichyne krylo" Ivana Franka v konteksti novitnikh yevropeiskykh mystetsko-kulturnykh poshukiv [Ivan Franko's "The Jay's Wing" in the context of the latest European artistic and cultural research] // Obraz [Image], 12, 19-25.

Calinescu, M. (1987). Five Faces of Modernity: Modernism. Avant-Garde. Decadence. Kitsch. Postmodernism. Durham: Duke University Press.

Chyrkov, O. (2006). Dramaturhiia - mystetstvo dramy? [Does is dramaturgy the art of drama?]. Visnyk Zhytomyrskoho derzhavnoho universytetu imeni Ivana Franka [Bulletin of Zhytomyr State University named after Ivan Franko] 30, 104-109.

Chyrkov, O. (2013). Salmakida, abo Dramaturhiia yak metavyd mystetstva [Salmakida, or Dramaturgy as an metaspecies of art]. In Literatura yak liudynoznavstvo [Literature as a human science], 335-352. Kryvyi Rih.

Denysiuk, I. (2001). Pro rodovo-vydovi osoblyvosti "Soichynoho kryla" [About genus-species features of 'The Jay's wing']. In Nevycherpnist atoma [Inexhaustibility of the atom], 3843. Lviv.

Durkalevych, V. (2007). Syntetyzm tvorchoho myslennia Ivana Franka (proza pochatku XX st.) [The synthesis of Ivan Franko's creative thinking (prose of the beginning of the XX century)] (Doctoral thesis, Ternopil National Pedagogical University).

Franko, I. (1935). The Jay's wing. Ukrainian weekly 47-52.

Goyet, F. (2014). The Classic Short Story, 1870-1925: Theory of a Genre. Cambridge, UK: Open Book Publishers. https://doi.org/10.11647/OBP.0039.

Grabowicz, G. (1991). Commentary: Exorcising Ukrainian Modernism. Harvard Ukrainian Studies 15(3/4). 273-283. https://www.jstor.org/stable/41036432.

Huniak, M. (2003). Metamorfoza "vidliudka": povist-novela I. Franka "Soichyne krylo" [The metamorphosis of the hermit: I. Franko's novel-short story "The Jay's Wing"] // Visnyk Lvivskoho universytetu. Seriia filolohichna [Bulletin of Lviv University. The philological series], 32, 31-36. 
Jost, F. (2004). The Look: From Film to Novel An Essay in Comparative Narratology. In Robert Stam \& Alessandra Raengo (eds.), A Companion to Literature and Film, 71-80. Blackwell Publishing. https://doi.org/10.1111/b.9780631230533.2004.00006.x.

Korniichuk, V. (2004). Lirychnyi universum Ivana Franka: horyzonty poetyky [Ivan Franko's lyrical universe: horizons of poetics]. Lviv: LNU.

Kozlov, R. (2012). Khronotopika Frankovykh dram: teoriia, praktyka, interpretatsiia [Chronotopics of Ivan Franko's dramas: theory, practice, interpretation]. Kryvyi Rih.

Kozlov, R. (2018). The image of Grinchenko in the journalism of the MUR. Synopsis: text, context, media 4(24). 23-33. https://doi.org/10.28925/2311-259x.2018.4.3.

Lehkyi, M. (2019). Proza Ivana Franka yak psykhobuttievyi ta sotsiokulturnyi fenomen. Zahalni zauvahy [Ivan Franko's prose as a psycho-living and socio-cultural phenomenon. General remarks]. Slovo i chas 2. 12-25. https://doi.org/10.33608/0236-1477.2019.02.12-25.

Lutsak, S. (2000). Vnutrishnia orhanizatsiia prozovoho tvoru: Na materiali "Soichynoho kryla" Ivana Franka [Internal organization of a prose work: On the material of "The Jay's Wing" by Ivan Franko] // Visnyk Prykarpatskoho universytetu: Filolohiia [Bulletin of the Precarpathian University: Philology], 5, 145-153.

March-Russell, P. (2009). The Short Story. An Introduction. Edinburgh: Edinburgh university press.

Muravetska, Y. (2018). Realism in the theoretical interpretation by Ivan Nechui-Levytskyi. Synopsis: text, context, media 3(23). 17-25. https://doi.org/10.28925/2311-259x.2018.3.2

Nakhlik, Y. (2017). Etapy Frankovoi evoliutsii [Stages of Franko's evolution]. Zbruč. https://zbruc.eu/node/61919.

Pier, J. (2003). On the Semiotic Parameters of Narrative: A Critique of Story and Discourse. In Tom Kindt \& Hans-Harald Müller (eds.), What Is Narratology? Questions and Answers. Regarding the Status of a Theory, 73-97. Berlin, New York: Walter de Gruyter.

Tarnawsky, M. (1991). Modernism in Ukrainian Prose. Harvard Ukrainian Studies 15(3/4). $263-$ 272. https://www.jstor.org/stable/41036431.

Tykholoz, B. (2009). Filosofska liryka Ivana Franka: dialektyka poetychnoi refleksii [Ivan Franko's philosophical lyrics: the dialectic of poetic reflection]. Lviv.

Vekua, O. (2002). "Semper tiro" Ivan Franko. Literaturoznavchi studii [Literary studies] 2, 5254. Kyiv. 